$\frac{\mathrm{DE}}{\mathrm{G}}$
DE GRUYTER OPEN
Research Article

(C) 2018 Adi Sumandiyar. This is an open access article licensed under the Creative Commons Attribution-NonCommercial-NoDerivs License (http://creativecommons.org/licenses/by-nc-nd/3.0/).

\title{
The Relation between Business and Authority: Maros Political Atmospheric Study in Indonesia
}

\author{
Adi Sumandiyar \\ S3 Sociology Students Graduate Program, \\ The State University of Makassar
}

Doi: $10.2478 / m j s s-2018-0087$

\begin{abstract}
The purpose of this study is to get the in-depth information about the patterns of relationship between the authorities and business groups on the political atmosphere in Maros, Indonesia This research was conducted using qualitative method with a constructivist approach. Data were obtained through advertising and electronic media in which the researcher acted as the research instrument. The data were used to investigate the relationship between the authorities and entrepreneurs on the political atmosphere in Maros, Indonesian The sources consisted of documentation and informants. The technique used in this study was in-depth interviews. Furthermore, the data were analyzed by interactive analysis intended to look at the process, the meaning, and the effect of the production and reproduction of the discourse. The results showed that the power of relation between the authorities and business groups had two objective and subjective dimensions and reacted reciprocally in producing up to reproducing the discourse of power that resulted in support for the authorities group of top level, midlevel, and the lowest authority levels in the region.
\end{abstract}

Keywords: Discourse, Authority, Politics, Business

\section{Introduction}

Political relations in the Group of authorities allow the business class to build patterns of cooperation through social and familiar approaches. On the other hand, the relationship between politics of economy and powers within the framework of the political atmosphere is that the company only utilizes natural resources and overrides adverse impacts on the environment that triggers the process of environmental degradation. Meanwhile, other negative effects are the utilization of human resources and development posing a dualism problem, which consists of the strength of the pattern of social structure (the relation factor) and the structure of the material (socio-economic conditions and the morphology of the territory). In conjunction with that, national study about authorities and businesses relation has also been widely publicized on some results of the research and academic forum. From the results of previous research, this report refers to a capital approach (epistemology) particularly in this study. As stated by Bulkhin, 1983; Mas'oed, 1989; Brown, 2006; Amri, 2010; Achwan, 2011; Djani, 2011; Innah, Darmawan, Suharjito, and Darussalam, 2012; and Suyatna, 2012, from the research that the authors summarize and have in common that authorities and businesses relation are quite apprehensive to the extent of co-optation of political power, the political economy in the political atmosphere, as well as the maintenance of political institutions and bureaucracy prevailed in Indonesia. Besides, it also raises pseudocapitalism. In sum, the emergence of businessman or black conglomerates is in the process of management and utilization of natural resources to benefit only for their own group. The group we mention is the authorities and businesses communities who build and establish relationships in 
perpetuating their efforts. Furthermore, raising the political and economic climate is created among the bourgeoisie with authorities holders trapped in the dimension of pseudo-capitalism dominated by businessmen who have a big capital.

In relation to that, a businessman who does not optimally have direct access to the authorities cannot manage the natural resource. Natural resources are already part of the scenario of the authorities given to the business groups that specifically have the proximity (patron-client). The pattern of relationships among the authorities and business groups is not as simple as it is narrated in the concept of state capture tinged with the pattern of relationships among the elite groups in charge toward a business group. This is shown if business groups want to reach out directly to the public resources, some of which hold public office, including the parliamentary seats. Meanwhile, relations that are awakened by the economic profile is dominated by public sector (state-driven economy) that makes entrepreneurs become very dependent on the ruling elite groups. Thus, it is very contrast with the concept of state capture.

Substantively, previous research studies are concerned in the theme of relations of authorities and businesses discussing whether it is done in the context of international and national patterned on two main studies. First, some researchers suggested benefits and contributions generated through the relation between companies and countries that bring benefits on both sides and do not give a positive impact on society. Secondly, there are patterns of relationships conducted by both parties with regard to the rules that affect the environment or even the rules themselves designed to make the easiest progress of working process with a company possibly by giving bribes or commit collusion. Several scientific publications clearly shows that the political atmosphere still revolves around the classical tradition, in which the ontological reality is limited to the structural problems (social relations) and material problems (ontology relationship).

In connection with this, the political atmosphere has not kept its promises because it fails to provide a "road map" of ideology and operation towards economic development which is fair and equitable. This failure comes from a weakness in the field of political economy which initially lays on the foundation of political force but was subsequently defeated by the atmosphere of political interests. Novelty ontology as a state of the art research is then amplified by the sociological fact which indicates that the relation of power and business studies political atmosphere are contained in any activity development of companies located in the district of Maros and always decorated with the "clash of discourse" as a form of representation of multi-factor interests. On one hand, discourse reproduction that states (Thesis) the growth of company becomes more productive in activities as the main factor of the regional development through local revenue, employment, and is followed by economical informal sector growth and also poverty reduction. On the other hand, discourse reproduction of resistance (antithesis) which looks at the practice of the development of the company indicates a patron-client relationship between the ruling group and business group coming with an interest encased in a particular clan master and setting the policy direction related to the development of companies in Maros.

The existence and development of the company in Maros regency in the middle of social resistance can be caused not only by their real contribution to the welfare of society, but also their illicit relationship between the authorities and businesses. Therefore, this research comes up with the question to investigate the relationship pattern between the rulers of authorities and employer groups on the political atmosphere Maros in Indonesia?

\section{Research Methods}

This research was conducted using qualitative method with a constructivist approach. Data were obtained through advertising and electronic media in which the researcher acted as the research instrument. The data were used to investigate the relationship between the authorities and entrepreneurs on the political atmosphere in Maros, Indonesian The sources consisted of documentation and informants. The technique used in this study was in-depth interviews. Furthermore, the data were analyzed by interactive analysis intended to look at the process, the meaning, and the effect of the production and reproduction of the discourse.

The research location was situated in Maros South Sulawesi province, Indonesia. the 
informants in this study were 16 people selected by using random sampling. The type of research data needed was primary data in the form of discursive practices (production and reproduction of discourse) and secondary data in the form of non-discursive practices (social events, economic and natural events) accompanying the group of power relations and business group as well as the result of the company's growth in Maros. Stages of data collection and analysis follow the cycle and take place continuously until complete, so the data becomes saturated. The concept includes data reduction, data display, and conclusion: drawing or verifying.

\section{Results and Discussion}

\subsection{Welfare discourse formation of companies}

Grouping discourse formation of companies welfare is a social reality that is built by two fundamental concepts i.e. authorities and knowledge. The birth of authorities by consciousness as a ruling class holds the power that open space in the established pattern of relations with entrepreneurs to develop businesses and immerse investment. Meanwhile, the practice of knowledge by leveraging the geographical conditions of the region, for example, the availability of land and Natural Resources (SDA) serves as the area development company.

The development of the company in various forms and manifestations has formed knowledge for the layman group about the company's presence both economically and socially through the creation of business climate. Citizens who belonged to the layman group assume that the status of the company development is a blessing and luck that can improve their social economy. Then this presumption is transformed into the leading energy driving the initiative to form the containing support so that the ruling class disburses all forms of discourse, so the facing can be easily accepted.

Formation corporate welfare discourse according to the logic above is a reality that is constructed by the attitudes and behaviour of the ruling class in the socio-economic life of citizens by making discourse. As stated by Foucault (1980), the power spreads everywhere (power is omnipresent). The power worked continuously in creating knowledge. In connection with it, the power always works through the construction of knowledge and the reason, in synergy with each other. The power is not possessed by another purpose that is not solely concentrated in the hands of individuals or the dominant structure, either by country, company, or organization, but rather by the power permeated the entire fabric of social relations-braid (Foucault, 1977 ).

The Foucault's point of view mentioned earlier still occurs nowadays particularly in terms of social welfare caused by the company. If Foucault theoretical view recognizes that power is not possessed in order to face the power of externalities, then this is contrary with the corporate discourse on welfare that has a philosophical awareness to citizens. The discourse of this corporate is manufactured and argued by the ruling class through the concept of extraordinary optimism milling to provide space support from the citizens in minimizing the effect of the actions of resistance and protest to the complexity often voiced by environmentalists and community leaders who focus on environmentalists.

Some of the ruling classes who have created their discourse begins to build strength by leveraging their knowledge. The rulers who are aware of this know this tendency very well, the strength of their authority will be able to bring relations with investors to immerse stocks and develop the company. Constructivist scheme played by the ruling executive agencies is the result of cognitive cooperation in interpreting relationships with entrepreneurs either by the existing entrepreneurs or with the new ones in order to build the cooperation between multi actors. As we all know particularly in this research the ruler of the executive branch refers to the government. The next government who takes the control system of government, bureaucracy, and political parties in the region contributes to the accountability of the mandatory entrusted to the head of the area.

Awareness of this collaboration then reflects in the existing power, and this is practiced in every postulated discourse. It occurs when the authority creates the discourse of welfare through the development of companies and industries in Maros. As affirmed by Foucault (1972), concerning the establishment of regulations discourse (the discursive regularities) covers several aspects, 
namely the object of production, production modalities of delivery, production concepts, and production strategies. This various discursive regulations determine an individual in sorting, classifying, and grouping the discourse about right and wrong, which ones are legitimate and which are not. Thus, the formation of discourse determines the pattern of social structure and pattern of the material structure. Therefore, it does not capture the realities of the power that is visible merely on the surface, but find and interpret the regularity of discursive formations as post-structural tradition. Discursive formations in human social relations do not stand alone and autonomously within the framework of objective truth, but the discourse becomes an integral part of the process and mechanisms of power.

Regarding to the formation of Foucault's discourse as confirmed by facts and data exploration results of research in Maros, the discourse structure is systematized by a ruling class that has an interest to develop the region. These groups of interest mentioned are the authorities of the executive. They are actually the ones that have an interest on behalf of regional development regarding the success in the regional industrial development-based development model by producing the arguments of the growing discourse among citizens, especially those who have a limited level of knowledge on Human Resources (HR). Therefore, the discourse itself also manages to enter the citizens' subconscious mind and considers it a form of success made by authorities of the executive institution so that the authorities of executive institution are labelled successful in their government. Consequently, the cognitive cooperation between the authorities of executives with a group of businessmen can be established i.e. the cooperation in terms of the regional development interest in the name of the locally-generated revenue development (PAD).

An interesting finding from the results of exploration and experiment in the study also come from the discourse of company and industrial development which is never found by the ruler of the legislature that produces welfare discourse that comes from the company. Generally, the authority of the executive produces this welfare discourse. The general meaning and subjective meaning from the discourse are then interpreted into a pattern of power relation that domain is owned and produced by the authority of the executive. Ruler of the legislature later then knows that the ruler of the executive in the stage of implementation is often shut themselves in the pattern of relation with entrepreneurs. It will be known when the industrial development program is about to be unveiled by the authorities of the executive institution.

Based on the these findings that the discourse of welfare are often argued by the executive institution that remains in line with the Foucault's view (1972), the discourse is characterized by the limitation of the object field, definitions, and perspectives of the most trusted and considered to be correct. Production and reproduction of discourse in the battle arena of multi-interests will produce dominant patterns of discourse and the discourse of the marginalized as the effects of contestation discourse.

Executive institutions produce discourse through the presence of the company's development for the welfare, however, the authorities of the legislature are often not aware with the company's development program. In fact, it is later known that the executive institution has established a partnership with entrepreneurs and investors to develop the company and to immerse shares. The viewpoints of other discourses produced by the authorities of the executive institution are on their Corporate Social Responsibility (CSR) during the development of big business which as well helps the citizens care about their community development, additionally it also helps increase original revenue (PAD) in Maros. The impact of this is that the impetus for the authorities of the executive to cooperate, but it can not be denied also that the source of the increase in revenue mostly from companies operating in Maros, because other sources of local revenue also come from the tourism, agriculture, and other leading sectors in Maros.

The social structure is the proximity factor between the rulers and businessmen. Employers often take advantage of the proximity factor for subsequent political lobbying regarding to the budget and passed a plan of activities undertaken in the project area. Meanwhile, the structure of the material is covering the scope of projects undertaken. How big the advantage of the project work also comes from multifactor inputs that play important role in passing the further project that is treated separately. Consequently, when evaluating the expected outcome the result is far from reality. This dimension often makes citizens become giddy, on one hand, the project is functioned 
as a facility and the main means of supporting all the activities, but on the other hand the project is not in line with expectations expected by citizens.

\subsection{Formation of discourse risks companies}

In understanding the discursive formation, Foucault (1972) argues that archaeological approach is intended to assess the differences of discourse in each scene of civilization. In this case it is known that there are two kinds of contradictions namely; (1) the contradiction that only appears on the surface that will be lost if the unity of discourse is observed extensively; and (2) involving various fundamental contradictive discourses. Foucault (1972) argues that further archaeological approach, positivity interpreted as a sphere of communication (unified discourse) of a discourse that is scattered everywhere. Where the use of benchmarks is a priority in historical statement contained in any factor, resulting in a medium that uses the archive. Historical prior discourse contained in any statement of the actor that led to the use of the archive is the discourse of the violations caused by the operation of the company. Damage and destruction of the violation in question is an endemic area resulting in the ecology of karsts rock that is possibly endangered. The violation is in which the company was found to be in accordance with their operational license to conduct exploration and exploitation activities around the area of karst ecology in Maros. Meanwhile, the discourse discursive milling sourced from discourse risk companies created is the only ruling siding with the businessmen. Other discussions are also on their Political and interest conspiracy among authorities and businessmen to create a policy that is more likely to favour businessmen than the welfare of the citizens. These policies are often created by licensing company that does not think of the interests of society in general, especially those who stay at the location of the company, and then the company permission is issued through collusion between authorities and businessmen.

According to the impressive views in the production and reproduction of Foucault discourse, it is something that Foucault describes as discontinued, hold, series, and cracking (rupture). Foucault (1972) states that every period of civilization undoubtedly has its own uniqueness. The specificity of each civilization identity determined by three dominant pillars, such as; (1) discourse; (2) power; and (3) knowledge. These three components can not be mutually separated, inasmuch as these three pillars synergize with each other in the civilization of knowledge (episteme).

The discourse concept that is often argued by the government who often produces the assumption that the company development is a particular supporting aspect in the improvement of the region's economy. However, the environmentalis and the society argued that such condition has brought detrimental impact to the surrounding. Furthermore, the concept of authority is a natural right that belongs to the authorities in producing a discourse to affect or even to create a positive statement that is used to influence the public paradigm, thus it could be accepted by the communities.

Another concept which is usually applied by the governemtn is the establishment of company development regulation model by modifying a number aspect. As consequence, people will perceive themselves as being made free from discrimination and regard it as a friendly evironmental company. Regarding the objective to investigate the cracks (ruptures) civilization of each episteme series, Foucault (1972) refers the concept of archaeology approach requires researchers to examine the features of civilization because episteme is not the one which appears in civilization, but what has been hidden behind its science domination in the past.

An interesting point in the studies is that the companies are suspected of damaging the ecology of karsts through the creation of business climate. Companies that created the business climate are often alleged to have committed the act of damage the environment. This allegation has a variety of motives, ranges from exploration to exploitation, dredging soil, destruction of roads, air pollution due to dust, pollution of the environment through waste company's operations, damage to biodiversity, and cracks that occur on the wall of rocky mountain and has carvings of original ancestors' image. Meanwhile, the company business model programs and projects promoted by the government are rarely found trespassing and damaging to the environment because of their business focuses on providing goods and secrive. Understanding the discourse on ideology inserted in discourse practice depends on the views, expressed the ideology as a practice that is 
operated in daily meaning production, on the contrary, the meaning is mobilized to maintain the power of relations (Thompson, 1990). This focus is contrast with the conception of ideology in many Marxist approaches. Marxists are not interested in the structure of certain ideologies, or on how an ideology is articulated in specific social contexts. However, they have provided ideology treatment as an abstract value system that is functioned as a social appeal (social pulling factor), which is interesting and binds people together thus strengthens the social order.

Based on the Fairlough theory; Chouliaraki and Thompson, the phenomena of relation in authotrities and in business in Maros is identified through the discourse of complaints occurred among citizens, especially for local residents who felt the impact of the un-integrity through the environmental damage is caused by the exploration and exploitation activities made by the company. An exploration and exploitation activity then becomes a scourge worrying the people as a threat of the crop fields and also the occurrence of abrassion around the river mouth affecting the agricultural productivity. The response of the discourse mentioned by the excevutive authorities is argued through the permissions that have been bagged by these mining companies which are in accordance with the mechanisms and rules revailed. Starting of licensing of Environmental Impact Assessment (EIA) to Environmental Monitoring Effort (UPL) conducted by the Department Regional Environmental Agency (BLHD) are the same with the existing mechanisms. Besides, the authorities of the legislature state another pretext i.e. when the company wants to set up citizens to agree for signing an agreement to establish a company agreement with all the risks that will occur in the future.

Based on Gramsci's theory of hegemony that was developed by Fairlough and Laclau, the truth of social reality is the ruler producing discourses for increasing revenue (PAD) to argue the opinion that the company's development was a blessing for the region especially for the citizens of the local community. Based on the availability of employment opportunities and the potential effect the economic improvement of the community. Ruling group then claimed that the group had succeeded in delivering its territory to escape from poverty after increasing the PAD obtained from the company development, hereinafter referred to as the creation model of social phenomenon selfimage for the rulers in perpetuating his power which often also leave the parties' color in making political decisions and ruling himself as a politician, in order to perpetuate its power. This is in line with what Laclau and Mouffe said related to the concept of meaning reproduction and substitution. In general terms, it refers to political act. Political in discourse theory should not be understood as an, for example, a political party's all mostly just talk about political representation and power. However, politics is regarded as a broad concept and refers to how we construct social phenomena in ways that the other ways. Laclau and Mouffe understand politics as civil society organizations from one particular side in a way that negates all possibility of other ways.

The concept of power in Laclau and Mouffe's approach is closely related to political concepts and objectivity (Laclau, 1990). Power should not be understood as something that belongs to the people and is exercised over others, rather something that can generate a social world. It may seem strange if you use the word "power" to describe the power and process to create our social world and make the social world to be meaningful for us. However, the understanding of this rule is emphasized on the dependence of the social world. The power of authority is the one who created our knowledge, our identity and how we relate to each other as a group or individual. Knowledge, identity, and social relationships depend on the particular time, they all produce a certain form, but it could have been and could be different.

\subsection{The political atmosphere in the pattern of power relations and business in Maros}

Data exploration motives political atmosphere in the pattern of power relations and business in Maros is so "sexy" to be used as experimental materials in this writing. This is due to the political motives of the atmosphere in Maros is full with wide range and variety of interests. A wide and diverse form of interests is contained in a success team during the election of Regional Head Candidate, as well as those who have a biological relationship or closeness with the Regional Head. Those who joined the Success Team in the election of candidate regional head are their backgrounds as businessmen, politicians, bureaucrats, public figures, to academics. The goal is to 
join and become part of the circle of political power. A wide variety of backgrounds has then opened the room to form a pattern of relationships between rulers and those who have a stake and support during the election of Regional Head.

Capital, power, and support are very important in a political atmosphere conditions. Especially for supporting background as a businessman with money, the consequences of political deals that happen are by way of policy transactions. Transactions of this policy often seen in the process and in the government work plan that directs the project, and project procurement services, to open the business climate. For politicians who have knowledge and expertise in formulating winning strategies in the future will be one of the policy makers, especially in the handling of construction and project tenders were considered to have a symbol of "wetland". As for public figures to the academics generally, they will be placed as part of a constituent or a team in the implementation of the wheels of government, such as expert staff. The focus of the study is those whose background as a successful businessman who has also made one of the candidates for the head election to sit on his authority chairs. So it is not an uncommon businessman who was willing to sacrifice all its resources indirectly already pocketed "memorandum tickets political agreement" between the rulers who have been successfully elected in the election of Regional Head.

A political agreement is continually used as a reference to create a program that leads to the development but not least also for the splashing of consensus among employers with rulers who had already had a political promise during the campaign first. This can be observed in the early days after the announcement of the establishment of the Regional Head. We can check through the sudden emergence of foreign investors-burying its stake to develop the early days of the Regional Head office. Transaction policy of the relationship pattern between authorities and entrepreneurs is generally in the form of construction of new buildings, renovation of the new building, repaired facilities and roads infrastructure, concreting program, program lighting street lamps and decorative lighting, as well as improving crop median along the streets of the capital. One of the transaction is often found in several inaccuracies and irregularities including for example the program that is not in accordance with the aspirations of citizens, then the program is not targeted therefore inversely proportional to what is expected by citizens. The Regional Head-building in accordance with the vision of their mission causes the program mismatches during the campaign that is not consistent with the fact that occurs in the field. In this vision and mission often inserted interests among the political groups multifactor playing backstage power. This is in harmony with the thought Hay, 1997 (Keith Faulks, 2012), the basis of the establishment of Hay, which proposes that any analysis of power consider these factors, among others: (1) the type of power; (2) the resources of power; (3) the method of power; (4) the power structure, (5) the site of power; and (6) as a result of power.

The findings in this research exploration ranges from the aspects of power relations and business. There are three important dimensions that occur in the political atmosphere phenomenon in Maros, Indonesia. First, the dimensions of power can be influenced by political relations and businesses that have been built during the run as Regional Head Candidate, secondly, the dimensions of power have a pattern that are dynamical according to the needs among multifactor in which there are some political interests and businesses to change the development of the policy direction, third, the dimension of power is more likely to lead to the aspirations of the relationships built through political conspiracy and businesses. These three dimensions are often struggling and milling in Maros area of political atmosphere in Indonesian.

\section{Conclusion}

The conclusion that can be formulated in this study is that the relationship with the ruling group and business owner groups on the political situation in Maros grows and expands in two dimensions: subjective and objective dimensions. Both of these dimensions influence reciprocally in producing up to reproduce the discourse of power that resulted in support for the ruling group top level, intermediate level, to decline to its lowest level in local authorities. Support this power is also expected to flow to communities with the hope that the cooperation program which the authorities and entrepreneurs who have succeeded and received a positive response created. At first the discovery of the relation employer groups subjectively understood as a relationship to develop the 
potentials of the region through equity investment, the development of the business sector, the development projects and programs of the ruling as well as the creation of business climate.

While objectively, in practice, in which the actor entrepreneurs engaged in the execution of projects and government programs generally they have closeness with the authorities. Pattern is seen in the proximity of family relationships as well as a board member of the ruling political party. So it is easy to obtain the information for entrepreneurs to work on the project activities and programs that have been planned in advance by the authorities. In the construction activities of project activities and programs of the government, Violations of law are commonly found with powerful individuals who have authority to use the budget of regions or countries. Such violations include inflated price (mark-up) which is not in accordance with the actual facts, budget fraud (corruption), up to the extent to "kortapokrasi" activity (the company's corporate and bureaucratic) along with a ruler purposely conducting illegal cooperation between authorities and entrepreneurs.

This group of businessmen originated from this business situation are inseparable from previously designed political relations. Big businessmen own political relations are moving the mining sector that is currently on top of the ruler at the national level. So with the power and political power (bargaining politics), it can easily access and obtain the Mining Business License (IUP). Group of entrepreneurs engaged in the mining sector, on one hand, bring a positive impact on economic growth as well as some citizens and its contribution to the local budget (APBD). On the contrary, it is well negatively affecting the surrounding environment, namely; environmental pollution, destruction of biodiversity, pollution of air, soil, and water, until the damage to the ecology of karst in the area of mining exploration and exploitation. As a result, through discourse, power, and knowledge that produces a logic which is built by the authorities and employers through the reality of ordinary citizens who lack of knowledge to create a political atmospheric condition in Maros, Indonesia.

\section{References}

Achwan, R. (2011). Hidup Bersama Oligarki (Bisnis Pakaian Jadi di Daerah). Dalam Majalah Prisma Perselingkuhan Bisnis \& Politik; Kapitalisme Indonesia Pasca-Otoritarianisme, 32 (1).

Amri, U. (2010). Power Contestation and Environmental Degradation: Evidence from Bombana's Gold Mining Site, Southeast Sulawesi Province, Indonesia. Di muat pada jurnal POLITIKA, 1 (2), (Online), (http://ejournal.undip.ac.id/index.php/politika/article/download/2849/2533), (accessed on 13 June 2015).

Anonim. (1977). Discipline and Punish, The Birth of the Prison. New York: Random House.

Anatonim . (1980). Power/Knowledge: Selected Interviews and Other Writing 1972-1977. New York: Pantheon Books.

Brown, A. B. (2006). Indonesian Corporations, Cronyism, and Corruption. Journal Modern Asian Studies 40 (4), pp. 953-992, (Online), (http://search.proquest.com/), (accessed on 12 June 2015).

Bulkhin, F. (1983). Negara dan Masyarakat: Politik Indonesia dibawah Orde Baru, 1966-1978. Unpublished Dissertation. University of Washington.

Djani, L., and Saputro, P A. (2011). Membaca Relasi Negara dan Kapital di Tingkat Lokal; Sebuah Tawaran Kerangka Analisis. Dalam Majalah Prisma Perselingkuhan Bisnis \& Politik; Kapitalisme Indonesia PascaOtoritarianisme, 32(1).

Faulks, K. (2012). Sosiologi Politik (Pengantar Kritis). Translated of Political Sociology: A Critical Introduction. (1999). Edinburgh: Edinburgh University Press.

Foucault, M. (1972). The Archelogy of Knowledge. London: Tarvistock.

Innah, H. S., Hadi D. A., Suharjito, D., and Darussalam, D. (2012). Peran Dinamika Jejaring-Aktor Dalam Reforestasi di Papua (The Role of Actor-Network Dynamics on Reforestation in Papua). Jurnal Penelitian Sosial dan Ekonomi Kehutanan, 9(2), pp. 96-112. (Online), (http://forda-mof.org/files/Jurnal_Sosek_9-22012-5.Henry_Silka,_dkk.pdf), (accessed on 13 December 2014).

Laclau and Mouffe. (1985). Hegemony and Socialist Strategy: Towards a Radical Democratic Politics. Verso.

Laclau. (1990). Kapitalist Devlet Sorunu. Iletisim.

Mas'oed, M. (1989). Ekonomi dan Struktur Orde Baru 1966-1971 (Orde Ekonomi Baru dan Struktur Politik 1966-1971). Unpublished Dissertation. Ohio State University.

Suyatna, H. (2012). Dominasi Elite Lokal Dalam Arena Pengembangan Industri Kecil di Era Desentralisasi. In Majalah Prisma Perselingkuhan Bisnis \& Politik; Kapitalisme Indonesia Pasca-Otoritarianisme, 32(1).

Thompson. (1990). Ethics and Politics: cases and comments. Nelson-Hall. 